\title{
CS-35 - Detenciones en flagrancia a imputados en el marco legal del artículo 16 Constitucional y 146 del CNPP: problemática actual
}

\section{Detentions in flagrancy to imputed in the legal frame of the constitutional article 16 and 146 of the CNPP: current problematics}

Evelyn Y. Corzo, Arturo E. Jasso

División Académica Multidisciplinaria de los Ríos, Universidad Juárez Autónoma de Tabasco

*Autor a quien se dirige la correspondencia: artjasso_753@hotmail.com

\section{Resumen}

— sta investigación expone ciertas deficiencias que son evidentes desde que se implementó a nivel nacional el sistema - 1 procesal penal acusatorio; dado el énfasis, en capacitaciones y cursos de sensibilización que deben de recibir los operadores jurídicos para que sean erradicadas las malas prácticas, asimismo se busca que el proceso penal se aplique conforme a derecho y que la ciudadanía restaure la fe en el sistema penal. La presente investigación ha optado por analizar cuáles son las problemáticas que se han hecho evidentes en el momento de realizar las detenciones ya que muchos de los imputados quedan en libertad cuando los jueces de control, no califican de legal la detención que se realizó por las policías sin cumplir con el llenado de forma correcta del informe policial homologado o califican de legal la detención cuando hay datos de la existencia de violaciones en la detención, sin que se actualice alguno de los supuestos que para la flagrancia contiene el Código Nacional de Procedimientos Penales. Se realizó una investigación mixta con esencia documental en su mayoría, pero complementándola con consultas a páginas gubernamentales, encuestas al público en general y especialistas, donde se advierte que las detenciones han disminuido, debido a la protección del principio de presunción de inocencia; además la presencia de las medidas cautelares y la justicia alternativa en este sistema, da la oportunidad a quienes cometen delitos menores que cumplan su pena o sean procesados mientras están en libertad o den por terminados los procedimientos a través de los MASC.

Palabras claves: Delito, persecución, medidas cautelares, control de detención, procesal acusatorio

\begin{abstract}
$\mathrm{T}$ his investigation exposes certain deficiencies that have become evident since there was implemented on the national level the so called Procedural Penal Accusatory System; since emphasis has been done in the trainings and courses of sensitization that the juridical operators must receive in order that the bad practices are eradicated, likewise there is looked that the penal process applies in conformity with right and that the citizenship restores the faith in the Penal System. The present investigation has chosen to analyze which are the problematic ones that have become evident in the moment to realize the detentions since many the imputed ones stay at liberty when the judges consider the detention to be illegal this when it was realized become attached to right or in his case the detention is qualified of legally when there are proofs that violations have been committed to his, human rights. A mixed investigation was realized by documentary essence in the main but complementing her with consultations to governmental pages, you poll the public in general and specialists, where one warns that the detentions have diminished since there is presumed that the arrested person "It is innocent until the opposite is demonstrated "; in addition the presence of the precautionary measures and the restorative justice in this system gives the opportunity to whom they commit misdemeanors that fulfill his sentence or are processed while they are attending at liberty at all time to the procedural guarantees recognized in the National Code of Penal Procedures.
\end{abstract}

Key words: Crime, pursuit, precautionary measures, detention control, procedural accusatory 